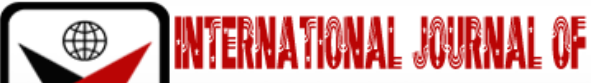

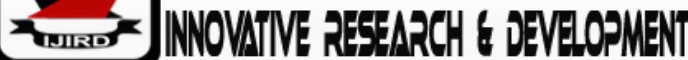

ISSN 2278-0211 (Online)

\section{Socio-cultural Significance of 'Cowdung' as a Natural and Renewable Bio Resource among the Traditional Nandi People of Kenya in East Africa}

\author{
Patrick Kimutai Tum \\ Lecturer, Department of Chemistry, School of Physical sciences, University of Nairobi, Kenya
}

\begin{abstract}
:
The current study explored the central role past and present of cow dung as a significant bio resource in the traditional life of the Nandi people indigenous to Kenya in East Africa. Cowdung is a byproduct of cattle rearing and is available in large quantities in every season. The women in the community were tasked with the collection of the dung from the kraals. The dung is removed as often as required still wet.In traditional Nandi sociocultural set-up, the number and nature of cattle found in the 'kraal' exemplified a source of wealth, prestige and well-being for the individual within the larger context of the community. The survival of the community throughout the seasons depended on the availability of cattle. The Nandi acquired cattle majorly by purchase, inheritance and 'bride-cattle'. In the past cattle were kept at the owners homestead or out in the grazing fields in the charge of a caretaker. The specified physical location where part of the cattle herd is kept was referred to as the 'kraal'. The calves are housed separately in a 'smaller kraal' and are considered subsistence resources in exchange and consumption. In modern Nandi society cattle husbandry remains both an industry and an occupation.In this study the 'complex' relationship and the sociocultural significance of cattle to the Nandipeople in Kenya was investigated by interviewing 40 respondents as subjects representing a diverse age group who were purposefully identified. The results reported show that the traditional Nandi people of East Africa utilizedcow dung as bioresource as follows: - [(building and construction, 41\% subjects); (cultural and religious symbolism, 17\% subjects); (Medicinal, 8\% subjects);( Agricultural (bio manure, 15\% subjects); (Fuel-cooking, 11\% subjects); (Styled hairdos and cosmetics, $8 \%$ subjects)]. In conclusion, the findings show that cow dung remains an important bioresource in the survival of the Nandi people in East Africa.
\end{abstract}

Keywords:Cow dung, bio resource, sociocultural, traditional, Nandi people

\section{Introduction}

One of the most notable characteristics of the Nandi people of East Africa is their 'relationship' with cattle which was labelled by Herskovits (1926) as 'complex'. In his observation Herskovits described the 'cattle complex' which consisted of a strong attachment to cattle in general which led to their use in several aspects of daily life. In Herskovits's words, 'cattlehave become the dominant element in the socio cultural way of life of the Nandi people'. The emotional attachment was frequently shown by affection and individual identification of these animals. He adds that cattle 'gather about them' additional cultural considerations that includes birth, death, marriage and other practices that remain rather complex and can be recognized wherever it existed (Herskovits, 1926). Considering that cattle were considered as a symbol of wealth among the traditional Nandi, the stock, collectively was considered as property belonging to the whole community. As a result of this belief, if cattle were lost by whichever cause, they had to be replaced (Kartikey, 2016; Matson, 1972). This is following a Nandi traditional saying that 'cattle are the foundations of all wealth'. The cattle consisted mainly of bulls, heifers and calves. Due to their vulnerability, the calves were kept in an enclosure next to the owners homestead. During the day when the calves are too young to walk about, they are kept tied using a rope under a tree or to a post (Hollis, 1909). Mature calves are allowed to roam freely in order to graze. The heifers and bulls are kept in a cattle kraal during the night and allowed to roam freely grazing during the day (Kartikey, 2016). Cow dung is a byproduct that results from the keeping of cattle. It can be defined as the undigested residue of consumed plant material being a mixture of faeces and urine in the ratio of 3:1. The cow dung mainly consists of lignin, cellulose and hemicellulose. In addition it contains many different minerals such as potassium, nitrogen, sulfur iron, magnesium, copper, cobalt and manganese (Garg and Mudgal, 2007; Randhawa and Kullar, 2011; Sawantet al., 2007)). From these composition it is evident that cow dung harbours a rich microbial diversity that includes various species of bacteria and other microorganisms i.e. (Bacillusspp, Corynebacterium spp. And Lactobacillus spp.), protozoa and yeast (Saccharomyces and Candida) (Nene, 1999; Randhawa and Kullar, 2011). Several researchers including Sawantet al., (2007) have isolated different bacterial genera that includes Citrobacterkoseri, Enterobacteraerogenes, Escherichiacoli, Klebsiellaoxytoca, Klebsiellapneumoniae, Kluyveraspp.,Pasteurellaspp., Providenciaalcaligenes, Providenciastuartiiand Pseudomonas spp. 
from cow dung. According to Adebusoyeet al., (2007); Akinde and Obire (2008); Umanuet al., (2013), cow dung contains various groups of microorganisms that include Acinetobacter, Bacillus, Pseudomonas, Serratiaand Alcaligenesspp., which makes it suitable for microbial degradation of contaminants. The cow dung within a given time frame transforms to manure which also plays an essential role in the lives of many plants, animals and microbes that includes insects like dung beetle and Pilobolus fungus (Akinde and Obire, 2008).In traditional Nandi society the cow dung was removed every morning by the women who scrapped it out with their bare hands using special sticks when the dung was wet and flung outside the kraal to be collected for use (Huntingford, 1950). Accordingly the different usage of cow dung reflected the knowledge associated with it since cow dung played a significant role in the community socio-economic livelihood (Dhamaet al., 2005).

\subsection{Nandi People of Kenya}

The Nandi people are Nilotic Kalenjin speaking community who are formerly semi-pastoral (Hollis, 1909; Matson, 1972). Traditional Nandi communities mainly kept cattle as an economic mainstay. The community was largely patrilineal, post marital residence is patrilocal, and however inheritance is patrilineal (Snell, 1954). A full set of brothers form a separate unit for property holding purposes. In traditional Nandi system the most important property was cattle (Snell, 1954; Huntingford, 1950). Snell further observed that the division of a deceased man's cattle was divided equally among the wives forming individual units. However cattle received through bride price is assumed to be part of a man's general estate was available for distribution in the same manner (Snell, 1954). This observation has also been reported by Huntingford (1950). In Nandi traditional society both a husband and wife can claim stake to ownership of particular animals. Cattle are associated almost universally with birth, death and marriage ceremonies (Hollis, 1909). As cattle are the major form of wealth, measure of power, prestige and status. Additionally the handling of cattle is accompanied by taboos in their handling, women were denied direct contact with cattle. There are special customs and taboos relating to handling of milk in traditional Nandi and entire Kalenjin society collectively (Huntingford, 1950; Kipkorir, 1978; Magut, 1969).

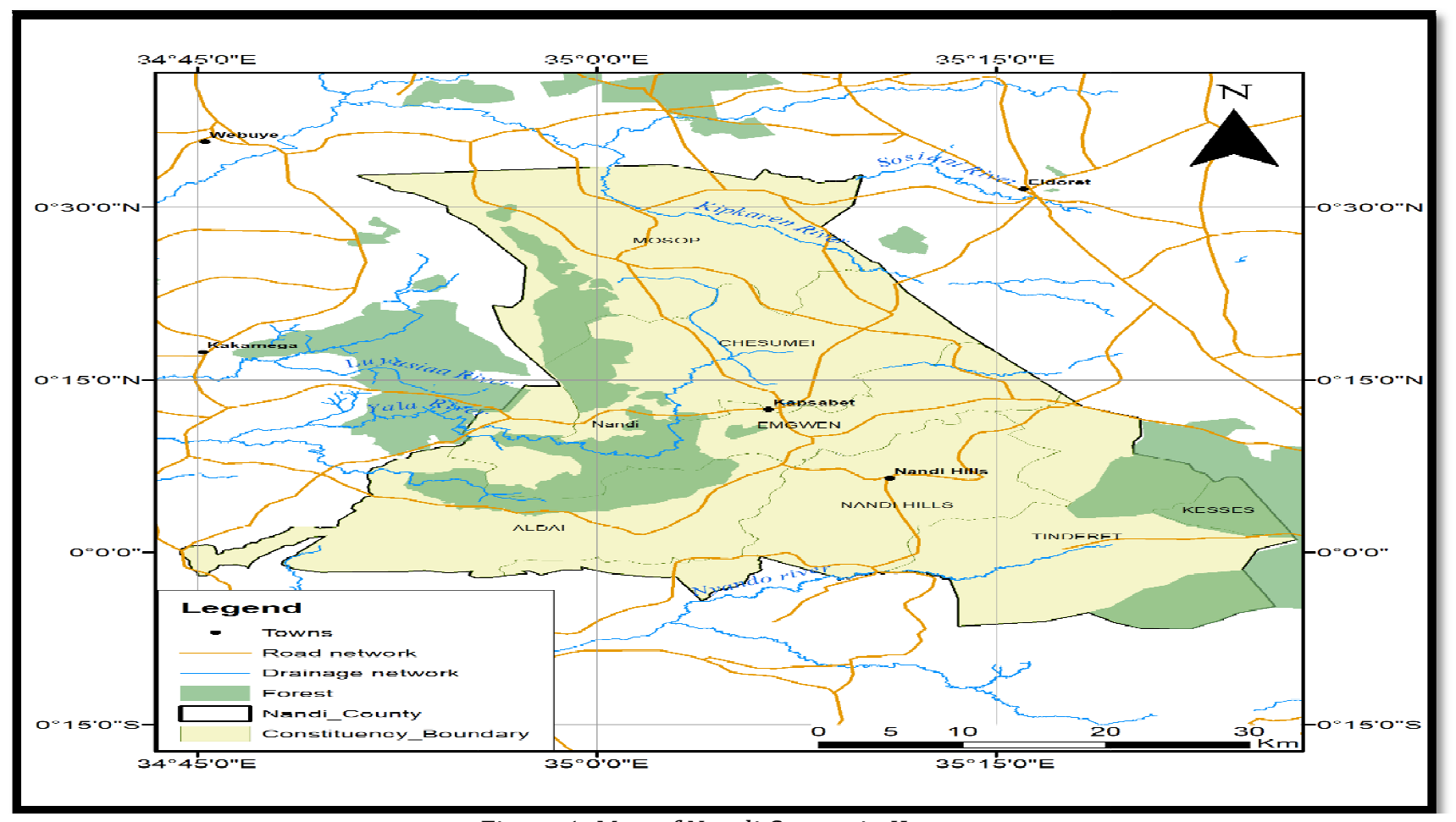

Figure 1: Map of Nandi County in Kenya

The Nandi people mainly occupy the County of Nandi in addition to several other counties within Kenya. Nandi County occupies $2885 \mathrm{~km}^{2}$ with at least $70 \%$ of the entire land mass or $2020 \mathrm{~km}^{2}$ is suitable for agricultural practices (Jaetzold and Schmidt, 1983). According to KNBS (2019), the population of Nandi County stood at 885,711 with the majority of residents found in the rural dispersed settlements (Oboler, 1985). The County receives substantial rainfall on average $1200 \mathrm{~mm}$ to $1850 \mathrm{~mm}$ per annum making it suitable for agricultural activities.

\subsection{Cultural Significance of Cattle in Traditional Nandi Society}

The major cultural significance of cattle in Nandi society was about living currencies. Cattle was regarded as living currencies' as they represent a living mode of exchange (Herskovits, 1926). Within the traditional set-up livestock signified how much wealth an individual held and the stock numbers would be guarded by the head of the family as well as instruct other family members on how to sustain the stock numbers (Hollis, 1909). The larger the stock held by a man, the more respect he received within the community. The respect also concerned the traditional knowledge, skills and experience in livestock health, reproduction and rearing (Snell, 1954). The holding of large stock numbers meant possessing knowledge that was sought after by community members. However with the advent of colonialism that 
resulted in imposition of taxes on homestead members and cattle changed such practices and associated processes. (Ngeny, 1972). Men were forced to leave their communities and take up employment in the cities and in Boer and British farms to be able to pay for the imposed taxes and levies (Oboler, 1985; Ngeny, 1972). Previous practices had laid taboos on women participating in the raising of cattle. However the developments necessitated the transfer of some responsibilities of livestock care to women. Initially the role of livestock rearing for women was restrict to goats, chickens and sheep (Walter, 1970). Cattle remained the domain of men who were consulted on all matters concerning cattle (Huntingford, 1950). Livestock in Nandi traditional life exemplified a 'double character' as icons of 'traditional' order as weapons in the struggle over modern life. Cattle as opposed to money are a living source of wealth that naturally reproduces and not affected by economic fluctuations and remain a major survival strategy for the survival of the community (Oboler, 1985). Livestock were inherited by children from their father making the practice of children looking after livestock an important reality. This made the practice of livestock rearing an intergenerational learning process. The value of livestock as wealth was not equated to their monetary value but their symbolic value as wealth themselves.(Herskovits, 1926; Huntingford, 1950)

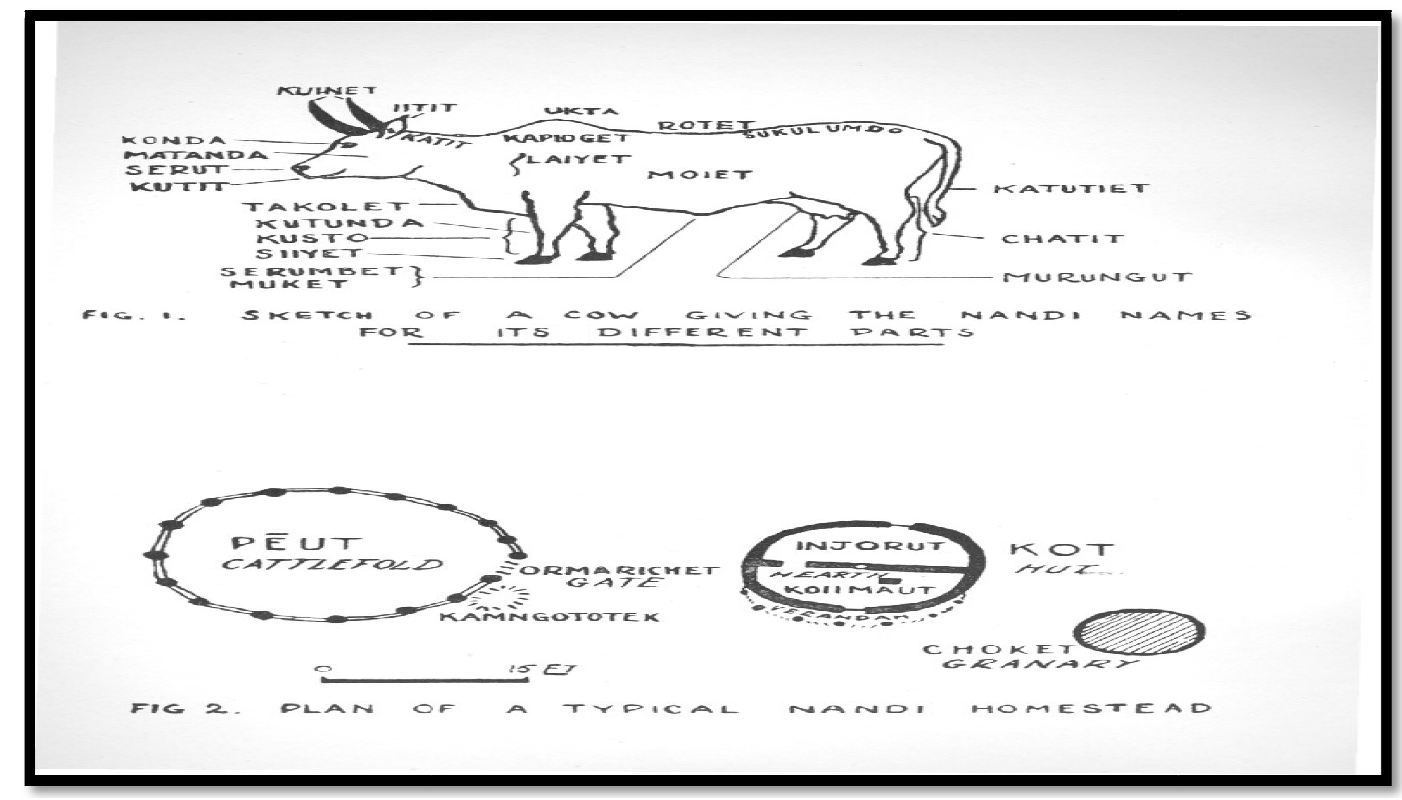

Figure 2: Layout of a Traditional Nandi Homestead and Various Body Parts a Cow (Huntingford, 1950).

Amassing livestock brought men great honour and respect. Cattle were also used to provide traction with the introduction of ox-drawn plough with livestock providing a more reliable livelihood resource (Oboler, 1985). The Nandi had various indigenous breeds of livestock specifically adapted to the local environment. Livestock were often used as a token of appreciation as a gift (Hollis, 1909). The gifting of cattle to children taught the values caring for the animals. Most traditional clothing was made from hides prior to the introduction of cotton and wool.

\subsection{Cattle as a 'Status' Symbol in Traditional African Society}

In African societies livestock represented a means of subsistence that was interwoven into the various facets of everyday life. Cattle signified access to food, security and wealth. In modern times traditional Africans were forcefully incorporated into the global capitalist monetary set-up (Schneider, 1964). Livestock had provided indigenous rural communities an alternative currency that was substituted by money currency (Schneider, 1964). The manner in which livestock were reared displayed the existence of a complex relationship between livestock, homestead subjects, belief systems and socio-ecological well-bring. Livestock maintained a social, economic, political, spiritual and ecological significance (Mukamure, 1970; Tsodzo, 1970). In Africa cattle remain by far the most valuable commodity. Goats and sheep were used as a media of exchange in most trade. All the various kinds of cattle i.e. cows, bulls and steers had different roles in the subsistence economy. Steers mainly served as a media of exchange and meat producers (Dore, 1970). Cattle were often sold to obtain cash money which was used to buy processed goods such as sugar, shoes etc. (Mukamure, 1970). Most fines in traditional African society was paid using livestock where the plaintiff was determined to obtain the largest fine possible and the defendant eager to make it as small as possible. The value of the defendant's total stock herd in supporting reciprocal obligations between neighbours and clansmen necessitated them to take sides in a legal dispute to minimize the damage of losing cattle. In a sense loss to one member of the community was a loss to all (Doran et al., 1979). On the other hand persons with interest in the plaintiff supported hum for his gain and also their own. The handling of livestock in African societies was accompanied by many taboos e.g. milk and meat have sacred qualities such that contamination by mixing the wouldcause ritual imbalance. Cattle were central to the valuation of one's wealth and social status (Doran et al., 1979). 


\section{Literature Review}

\subsection{Construction of Traditional Huts (Stabilizer)}

The application of cow dung in building and construction involved its mixture with mud and other substances to create a paste that was applied to the walls and floors of huts forming a water proof layer(Kumaret al.,2016). This layer of cow dung mixture acted as a thermal insulator (Kartikeyet al., 2016). This practice improved resistance of water and durability of plasters. The cow dung was used traditionally as a stabilizer. Apart from being a good binder, cow dung fibers present helped create a smooth fine floor finish in addition to preventing cracking while improving the insulation properties of the plaster(Paa-Kofi Yalley and Manu, 2013). Bricks made from mud if stabilized with cow dung tends to achieve better solidity and durable. These bricks can last for several years without developing cracks even under extreme stress. To improve the durability of mud houses, stabilizers like lime, wheat husk, straw dust and cow dung are used to prevent any damage. In Burkina Faso and Rwanda the application of cow dung as a stabilizer protects huts against erosion during rainy seasons (Paa-Kofi Yalley and Manu, 2013).

\subsection{Religious and Cultural Symbolism}

In all African religion and mythology cattle were considered to be sacred. The sky was envisioned as a goddess assuming the form of cow deities. In the southern part of Africa, the Setswana speaking people referred to cattle as 'God with a wet nose', thereby creating a conflation of the cow with notions of the divine. In these cultures cattle are considered beasts of providence (Park, 2013). Cattle are therefore considered central to the lives and diverse cultures of Africa's culture. In traditional African society cattle play a major role in the religious thought and practices of the various communities (Huntingford, 1950). Cattle were viewed as an extension of the human family representing ideals that the human community adopt as a belief system(Comaroff, J.L and Comaroff, J, 1990). The ideology and rituals of sacred kinship is personified through animal symbolism. The cows form symbols of divine and natural beneficence. The priests in the communities were identified with cows and it was considered a taboo to slaughter milk producing cows (Park, 2013). Religious practices however involved offering of sacrifices in the form of livestock. Livestock played mediation role between the living and the ancestors. Livestock including cattle therefore provided a spiritual currency to communicate with the community ancestors (Dore, 1970; Makamure, 1070).In most African societies ritualistic or religious slaughter required the animal to be in a state of consciousness consistent with other religions e.g. Jewish, Sikh and orthodox Islam (halal) slaughter.In many African cultures the kraal served as a hallowed ground for ritual activities in a family home. This space provided a ground for facilitation the living to the ancestors. Additionally a revered bull was set aside for traditional rituals of giving a sacrifice to the ancestors (Dore, 1970). The rituals involved the pouring of traditional beerover the bull as a form of libation accompanied by speeches of request for the well-being of the family. The reaction of the bull by shaking its head and bellowing was a sign that the prayers had been answered. The burial of a family member include the slaughter of a bull consumed during the funeral ceremony (Bere-Chikara, 1970; Mukamure, 1970).It was believed that the beast would accompany the deceased to the spiritual world of the ancestors (Mukamure, 1970).

\subsection{Medicinal Properties}

In traditional African societies cow dung found application as medicinal agent. This was shown by its application as an antifungal insecticide used to disinfect mud huts and floors (Khan and Manchur, 2015). Cow dung has also been noted for its antibacterial properties (Girijaet al., 2013). Some cultures apply cow dung to the wall of mud huts and floors as a disinfectant and insulator. The smoke from burning dry cow dung has been found to repel mosquitoes. This led to the deliberate use of cow dung as an insect repellant in most African societies (Knippling, 1949). Cow dung has also found application as a cleaning agent for kitchen utensils in addition to water disinfection (Akinde and Obire, 2008). Several researchers report that cow dung not only disinfected water but also improve its mineral content. Noting the antiseptic character of cow dung, it is used to prevent inflammation and pains. The treatment of burn wounds involved preparing a mixture of black mud, yeast dough made from cow dung, cereal made of barley, mashed beans mixed withwax (Encarnaet al., 2004; Lu et al., 2014). In its dry and powder form, cow dung has been used to treat skin disorders to reduce inflammation and improve blood circulation.

\subsection{Agricultural Manure}

The traditional African societies used cow dung as a fertilizer to improve soil fertility because of its high nitrogen content that is important for the development of plants (Adams et al., 2014). The communities were aware that cow dung manure made excellent fertilizer and were reminded of this every time they passed by a fertilized field of crops compared to an unfertilized field (Ewusi-Mensa, 2015). Cattle manure is exceptionally rich in minerals especially nitrogen, phosphorus and potassium. It further supports the growth of beneficial microorganism when mixed with soil (Safley and Westerman, 1990; Bernal et al., 2009). Manure also improved the texture of soil helping to improve moisture content (Mohapatra, 2008). More often since cow manure is rich in minerals and certain chemicals, it may require dilution by leaving out to sit in the soil prior to application to crops during planting (Yadav et al., 2013).

\subsection{Source of Fuel}

Dried cow dung formed an excellent fuel due to its excellent exothermic combustion. This was used instead of firewood. This is attributed to plant fibers (cellulose, hemicelluloses and lignin), fragments of intestinal tissues and amine organic compounds present in cow dung (Kalia and Singh, 2004; Islam et al., 2010). Cow dung also contains 80-90 wt. \% water. In some cultures dung from domestic cows or buffalo was routinely collected and dried for fuel. Pieces of dung are 
often lit to provide light and a flame for cooking. Dried cow dung loses its irritating odour (Mundaet al., 2012). In the modern world energy is stored in cow dung for subsequent use (Ranaet al., 2014). This is often done indirectly by making biogas from the dung. Biogas is a mixture of highly combustible gases synthesized from anaerobic digestion of organic matter by bacteria. The organic matter digested includes dung, sewage, plant material and food waste (Sanaei Moghadamet al., 2014). The digestion process to produce the biogas takes place in a biogas digester and the gas used as a fuel.

\subsection{Styled Hairdos and Cosmetics}

African men and women used cow dung as a source beautification of hair and skin. Cow dung was used to creatively innovate unique hairstyles. The hairstyles were made from adding to hair a mixture of butter, ochre, oil, crushed tree bark, herbsanddried cow dung (Schneider, 1964).In Angola the Mwila and Mumuhuila communities covered and styled hair with cow dung (Dore, 1970). In addition red ochre mixed with sheep fat was evenly spread into long braided hair. Ancient Egyptians produced cosmetics from materials present in their physical environment (Walter et al., 1999). The modern cosmetic industry has generated extremely pleasant smelling vanilla fragrance from cow dung. Excellent skin care products prepared from cow dung, urine and butter have been invented (Dore, 1970). In India soap from cow dung and urine has found widespread use for its good quality (Kartikeyet al., 2016). Lately personal care products prepared from cow dung include shampoo, shaving cream, sunscreen, face wash, incense sticks and under eye gel. Cow dung has been found to help in hydrating, nourishing, exfoliating and healing the skin.

\section{Research Methodology}

\subsection{Research Questions}

This research work intended to purposefully identify the historical socio-economic significance of 'cow dung' as a critical bioresource among the Nandi people of Kenya who form part of the Kalenjin speaking people in East Africa.

\subsection{Research Design and Questionnaire for Respondents.}

The present study identified 40 subjects to be interviewed in Nandi County. The subjects were purposefully identified and interviewed individually and their responses recorded using a tape recorder and questionnaire. Data used in this study was sourced from primary and secondary sources. To enhance data collection descriptive and explorative techniques were used (Kombo and Tromp, 2005). The explorative design was utilized in identifying the problem and reviewing related literature. . Descriptive design was used to interpret the data collected and provide a textured view of the subject under investigation (Kombo and Tromp, 2005). The field trips undertaken were structured with interviewed members of the Nandi community who comprised various age-groups. In-depth interviews were done to source specific information from key informants whose views and perceptions on the historical use of cow dung was obtained. Structured questionnaires were used to obtain bio data from prospective respondents to determine their suitability to participate in the study. The final data obtained was quantified using descriptive statistics like frequencies and percentages and findings presented using charts, tables and graphs (Kothari, 2004).

\section{Results and Discussions}

\subsection{Respondents by gender}

The respondents were interviewed considering their gender. The purpose was to obtain a diverse view on the subject matter researched. A total of 40 subjects were interviewed and their demographical categorization is represented in Figure 3 below:-

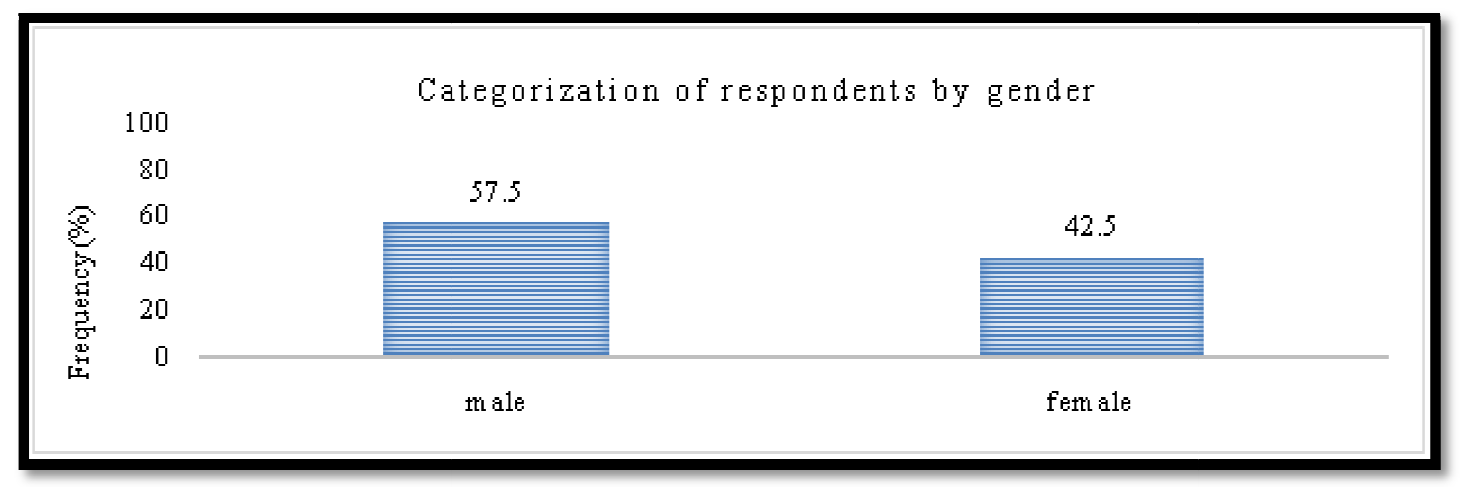

Figure 3: Gender Composition of Respondents

The findings reveal that more males (57.2\%) participated in the research study compared to their female counterparts (42.5\%). Out of the total 40 respondents, 23 males and 17 females took part in the survey. In addition the majority of the respondents were between the ages of 30-80 years. The participation of fewer females was influenced by cultural taboos that restricted the subject matter to the males in the Nandi community. 


\subsection{Age Bracket of Respondents}

A demographic representation of respondents according to their age range is presented in figure 4 below:-

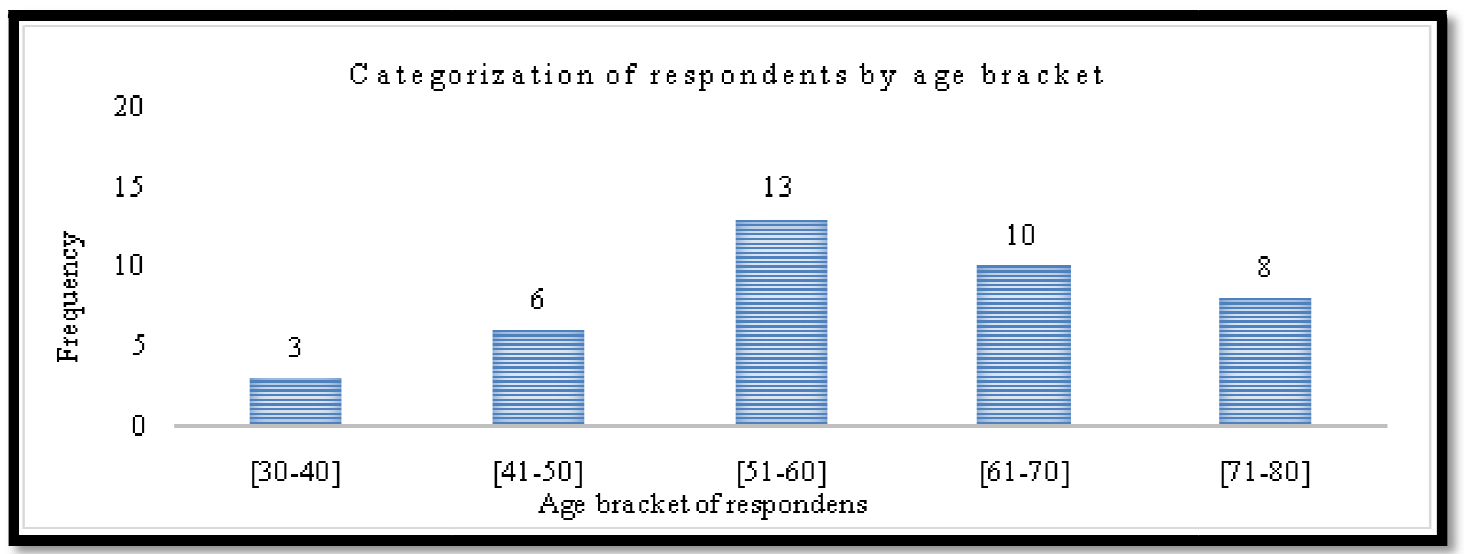

Figure 4: Age Bracket of Respondents

The respondents in the research study were clustered into five age brackets a shown in figure 4 . The findings indicate the following distribution: [( 3 subjects, 30-40 years); ( 6 subjects, 41-50 years); (13 subjects, 51-60 years); (10 subjects, 61-70 years); (8 subjects, 71-80 years)]. For this study, the greatest proportion of respondents 13 subjects were placed in the (51-60 years) age bracket. This represented (32.5\%) of the total number of respondents interviewed (40). In contrast, respondents in the (30-40 years) age bracket represented the least number of subjects (3) interviewed. This sample size represented $7.5 \%$ of the total number of respondents interviewed. Respondents in the (30-40 years) age bracket mostly rejected to be interviewed or proved to be less resourceful in their responses.

\subsection{Highest Educational Qualifications of Respondents}

The highest Educational achievements of the respondents that participated in the study is shown in Figure 5 below:-

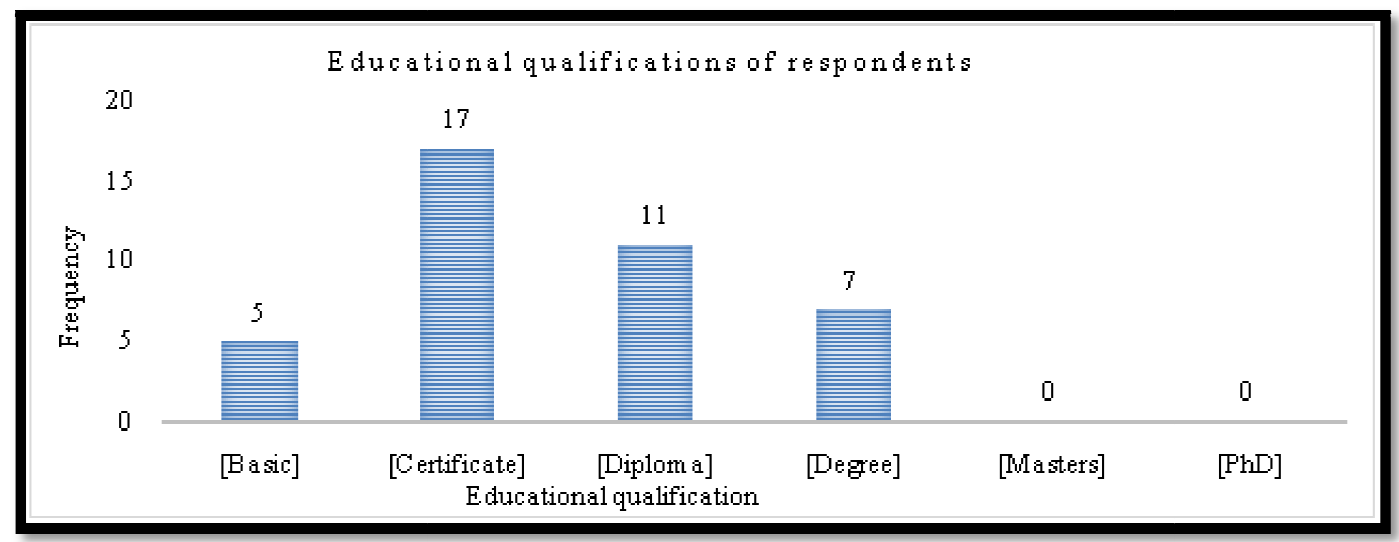

Figure 5: Classification of Respondents by Educational Qualification

The results in Figure 5 show that the majority of respondents (17 subjects, 425\%) that participated in this study held a certificate as their highest level of academic training. Out of the sample size of 40 subjects (5 subjects, $12.5 \%$ ) had attained basic education i.e. primary level.However a further (11 subjects, 27.5\%) of the respondents reported having attained a diploma level of training. Respondents with a university degree (7 subjects, $17.5 \%$ ). In this study none of the respondents reported holding a masters or doctorate degree.

\subsection{Ranking of the Sociocultural Significance of 'Cow Dung' as a Critical Bio Resource by the Respondents}

The overall responses provided by the respondents in the significance of cow dung in the sociocultural set-up of the Nandi speaking people is shown in Figure 6 below:- 


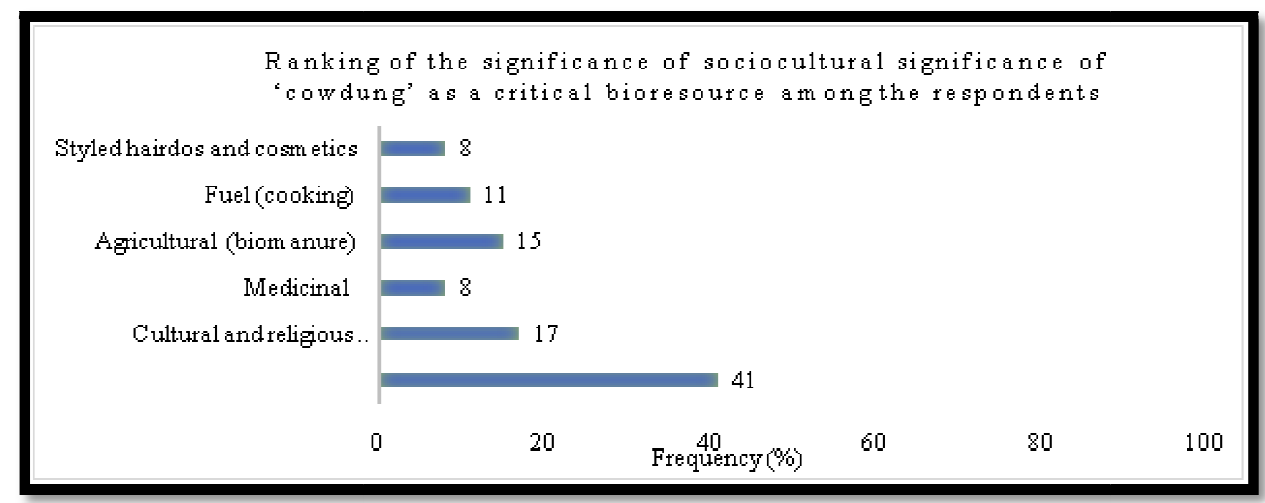

Figure 6: Sociocultural Significance of 'Cow Dung' among the Nandi People Found in East Africa

The respondents in this study (40), provided the following responses on the importance of cow dung in their traditional way of living. Their responses can be summarized as follows :-[( building and construction, $41 \%$ subjects); (cultural and religious symbolism, 17\% subjects); (Medicinal, 8\% subjects) ;( Agricultural (bio manure, 15\% subjects); (Fuel-cooking, 11\% subjects); (Styled hairdos and cosmetics, 8\% subjects)]. From the findings, cow dung was reported by a significant sample size of the respondents (41\% subjects) as a building and construction material for their traditional huts. In comparison further results show that the use of cow dung as a source of cosmetics and a medicinal derivative was reported by a relative small size of the sampled respondents ( $8 \%$ subjects).

\section{Conclusions}

The findings in this study conclude that cow dung as a critical bioresource found numerous applications within the life of the traditional Nandi people of East Africa. The resource was found to be inexhaustible and extremely rich in substances such as minerals, useful bacteria, fibre etc. that found numerous uses within the community. The survival of the tribe depended on the availability of cattle hence cow dung. The paper concludes that it was a taboo for women to participate in the rearing of cattle apart from the collection of cow dung from the family kraal. Individual ownership of several herds of cattle guaranteed the owner a good social standing in society and enhanced social class. The availability of cowdung in traditional Nandi complemented the planting of crops for consumption supported by abundant manure available from cow dung. The socioecomnic lives of the Nandi tribe depended on livestock as an independent living currency.

\section{Acknowledgements}

The researcher shows sincere appreciation to all the respondents that found time to participate in this study.

\section{References}

i. Jaetzold, R., \&Schmidt, H. (1983). Farm Management Handbook of Kenya. Vol. II. East Kenya (pp. 245-285).

ii. Oboler, R.S. Women, Power, and Economic Change: The Nandi of Kenya. Stanford University Press, 1985.348 pp. Volume 29 Issue 3.

iii. Snell, G.S. Nandi Customary Law; Macmillan \& Co. Ltd., London,1954

iv. Huntingford, G.W.B. (1950). Nandi Work and Culture. London, H.M.S.O. for the Colonial Office.

v. Matson, A. T. (1972). Nandi Resistance to British Rule 1890-1906. Nairobi: East African Publishing House.

vi. Kipkorir, B. E. (1978). People of the Rift Valley, Kalenjin. In M. Sharman, (Ed.). Kenya's People. Nairobi: Evans Brothers Limited.

vii. Magut, P. K. (1969). The Rise and Fall of Nandi Orokoiyot, C. 1850-1957. In B. C. Mclntosh, (Ed.). Ngano: Studies in Traditional and Modern East African History, Historical Studies, No. 1. Nairobi: East African Publishing House.

viii. Schneider, H.K. (1964). A model of African indigenous economy and society. Comparative

ix. Studies in Society and History, 7(1), 35-55.

x. Matson, A. T. (1972). Nandi Resistance to British Rule 1890-1906. Nairobi: East African Publishing House.

xi. Makamure, D.M. (1970). Cattle and social status. In C. Kileff\& P. Kileff (Eds), Shona customs:

xii. Essays by African writers, pp 14-16; Harare: Mambo Press.

xiii. Doran, M.H., Low, A.R.C. \& Kemp, R.L. (1979). Cattle as a store of wealth in Swaziland:

xiv. Implications for livestock development in Eastern and Southern Africa. American Journal of

xv. Agricultural Economics, 61(1), 41-47.

xvi. Walter, J. B. (1970). Territorial Expansion of the Nandi of Kenya, 1500-1905. Ohio University Centre for International Studies, Africa Programme.

xvii. Dore, L. (1970). The uses of cattle in Shona society. In C. Kileff\& P. Kileff (Eds), Shona customs: Essays by African writers, pp 24-26. Harare: Mambo Press.

xviii. Ngeny, S. K. (1972). Nandi Resistance to the Establishment of British Administration 1893-1906. In B. A. Ogot, (Ed.). Historical Association of Kenya, Hadith 2. Nairobi: East African Publishing House.

xix. Park, K.S. (2013). Christian spirituality in Africa: Biblical, historical, and cultural perspectives from Kenya. Eugene, OR: Pickwick Publications. 
xx. Schneider, H.K. (1964). A model of African indigenous economy and society. ComparativeStudies in Society and History, 7(1), 35-55.

xxi. Knippling, E.F. (1949). Mosquito repellent in Malariology Vol 2 Saunders, London.pp. 1175 - 1177.

xxii. Khan, S \&Manchur, A; a research on Activated cow-dung slurry as a tool to pesticides bioremediation2015.

xxiii. Paa-Kofi Yalley, P and Manu, D. (2013). Strength and Durability Properties of Cow Dung Stabilized earth Brick. Civil and Environmental Research, 3(13), 117-127.

xxiv. Kartikey, K.G., Kamal, R.A \&Deepanshu, R. (2016). Current status of Cow Dung as a bioresource for sustainable development. Bioresources and Bioprocessing, 3(28), 1-11.

xxv. Adams, G.0, Tawari-Fufeyin, P \&Ehinomen, I (2014). Laboratory scale bioremediation of soils from automobile mechanic workshops using cow dung. J Appl Environ Microbiology, 2, pp. 128-134.

xxvi. Akinde, S.B, Obire, O. (2008) Aerobic heterotrophic bacteria and petroleum-utilizing bacteria from cow dung and poultry manure. World J MicrobiolBiotechnol., 24, pp. 1999-2002.

xxvii. Bernal, M.P, Alburquerque, J.A and Moral, R. (2009) Composting of animal manures and chemical criteria for compost maturity assessment-review. Bioresour Technol., 100, pp.5444-5453.

xxviii. Dhama, K., Chauhan, R. S and Singhal, L. (2005). Anti-cancer activity of cow urine: current status and future directions. Int J Cow Sci., 1, pp. 1-25.

xxix. Dhama K, Rathore R, Chauhan RS, Tomar S (2005b) Panchgavya: an overview. Int J Cow Sci., 1, pp. 1-15.

xxx. Encarna, V.Z., Trinidad, D. M., Margarita, P., Rau, R., Ramo'n R, M and Toma, G.V (2004). Paenibacillusfavisporus sp. nov., a xylanolytic bacterium isolated from cow faeces. Int J SystEvolMicrobiol., 54, pp.59-64.

xxxi. Ewusi-Mensah, N., Logah, V and Akrasi, E. J (2015) Impact of different systems of manure management on the quality of cow dung. Commun Soil Sci Plant Anal., 46, pp.137-147.

xxxii. Garg, A.K and Mudgal, V. (2007). Organic and mineral composition of Gomeya (cow dung) from Desi and crossbred cows-a comparative study. Int J Cow Sci., 3, pp. 1-2.

xxxiii. Girija, D., Deepa, K., Xavier, F., Antony, I and Shidhi, P.R. (2013) Analysis of cow dung microbiota-a metagenomic approach. Indian J Biotech., 12,372-378.

xxxiv. Islam, M.R., Rahman, S.M.E, Rahman, M.M, Oh, D.H and Ra, C. S. (2010). The effects of biogas slurry on the production and quality of maize fodder. Turk J Agric., For; 34, pp. 91-99.

xxxv. Kalia, A and Singh, S. (2004) Development of a biogas plant. Energy Sources, 26, pp.707-714.

xxxvi. Lu, H., Wang, X., Zhang, K., Xu, Y., Zhou, L and Li, G. (2014) Identification and nematicidal activity of bacteria isolated from cow dung. Ann Microbiol., 64, pp.407-411.

xxxvii. Mohapatra, D., Mishra, D., Chaudhury, R.G and Das, R.P. (2008). Removal of arsenic from arsenic rich sludge by volatilization using anaerobic microorganisms treated with cow dung, soil and sediment contamination. An Int J., 17, pp. 301-311.

xxxviii. Munda, U.S., Pholane, L., Kar, D.D and Meikap, B.C. (2012). Production of bioenergy from composite waste materials made of corn waste, spent tea waste, and kitchen waste co-mixed with cow dung. Int J Green Energy., 9, pp.361-375.

xxxix. KNBS (2019). Kenya Population and Housing Census; Government Printer, Nairobi.

xl. Rana, G., Mandal, T and Mandal, N.K. (2014) Generation of high calorific fuel gas by photosynthetic bacteria isolated from cow dung. Int J Res., 1, pp.115-128.

xli. Tsodzo, T.K.M. (1970). Cattle are our bank. In C. Kileff\& P. Kileff (Eds), Shona customs: Essays by African writers (pp. 17-19). Harare: Mambo Press.

xlii. Safley, LM and Westerman, P.W. (1990). Psychrophilic anaerobic digestion of animal manure: proposed design methodology. Biol Wastes., 34, pp.133-148.

xliii. Sanaei-Moghadam, A., Abbaspour-Fard, M.H., Aghel, H., Aghkhani, M.H., AbediniTorghabeh, J. (2014). Enhancement of biogas production by co-digestion of potato pulp with cow manure in a CSTR system. ApplBiochemBiotechnol., 173, pp.1858-1869.

xliv. Sawant, A.A., Hegde, N.V, Straley, B.A., Donaldson, S.C, Love, B.C, Knabel, S.J, Jayarao, B.M. (2007). Antimicrobialresistant enteric bacteria from dairy cattle. Appl Environ Microbiol., 73, pp.156-163.

xlv. Herskovits, M.J. (1926). The cattle complex in Eat Africa. American Anthropologist, 28, pp. 230-272.

xlvi. Randhawa, G.K and Kullar, J.S. (2011). Bioremediation of pharmaceuticals, pesticides and petrochemicals with Gomey/cow dung. Pharmacology. (2090-5165:362459.

xlvii. Yadav, A., Gupta, R \&Garg, V.K. (2013). Organic manure production from cow dung and biogas plant slurry by vermicomposting under field conditions. Int J Recycl Org Waste Agric., 2, pp.21.

xlviii. Paa-Kofi Valley, P \&Manu, D. (2013). Strength and Durability Properties of Cow Dung Stabilized earth brick. Civil Environmental Research, 3(13), pp.117-127.

xlix. Nene, Y.L. (1999). Utilization of Traditional knowledge in agriculture. Traditional knowledge system of India and Sri Lanka, pp.32-38.

l. Adebusoye, S.A., Ilori, M.O., Amund, 0.0., Teniola, O.D and Olatope, S.O. (2007). Microbial Degradation of Petroleum hydrocarbons in a polluted stream. World Journal of Microbiology and Biotechnology, 23, pp. 11491159.

li. Walter, P.H., Martinetto, P., Tsoucaris, G. (1999). Making Makeup in Ancient Egypt. Nature, pp. $397-483$.

lii. Akinde, 0 and Obire, K. (2008). Aerobic heterotrophic bacteria and petroleum utilizing bacteria from cow dung and poultry manure. Journal of Microbiology and Biotechnology, 24, pp.1999-2002. 
liii. Kumar, K.G., Kamal, R.A and Deepanshu, R. (2016). Current status of Cow Dung as a bioresource for sustainable development. Bioresources and Bioprocessing, 3(28), 1-11.

liv. Hollis, A.C. The Nandi-their language and folklore; Duff Press, Oxford, 1909.

lv. Bere-Chikara, F. (1970). Cattle: The life blood of Shona society. In C. Kileff\& P. Kileff (Eds), Shona customs: Essays by African writers (pp 20-23). Harare: Mambo Press.

lvi. Comaroff, J. L. \&Comaroff, J. (1990). 'Goodly beasts, beastly goods': Cattle and commodities in a South African context. American Ethnologist, 17(2), 195-216.

lvii. Umanu, G., Akpe, A.R \&Omoikhudu\&A.R. (2013). Degradation assessment of bacteria from used motor oil contaminated soils in Ota, Nigeria. International of Advanced Biological Research.,3(4), pp.506-513.

lviii. Kombo, D \& Tromp, D. (2006). Proposal and Thesis Writing. An Introduction. Nairobi: Pauline Publications.

lix. Kothari, C. R. (2004). Research Methodology Methods and Techniques. (2nd ed.). New Age InternationalPublishers. 